LINGUAGEM MÉDICA

\title{
PROGRAMA E
}

\section{PROGRAMAÇÃO}

\section{Joffre M. de Rezende ${ }^{1}$}

Vemos com frequência nos programas de congressos médicos o emprego da palavra programação em lugar de programa. Embora considerados sinônimos, a rigor não o são. Somente dois dicionários admitem a sinonímia, talvez movidos pela convicção de que se trata de um fato da língua irreversível e consolidado. São eles o Houaiss (1) e o dicionário de Francisco Borba (2).

Programa provém do grego prógramma, com passagem pelo latim programma com o sentido de publicação escrita ou impressa. Aurélio define programa como um "escrito ou publicação em que se anunciam e/ou descrevem os pormenores de um espetáculo, festa ou cerimônia, das condições dum concurso, etc. "(3). Acrescentaria nesta lista as reuniões para apresentação e discussão de temas científicos como congressos, jornadas, simpósios, seminários.

Programação formou-se com o verbo programar mais o sufixo nominal ção, que indica ação ou o resultado da ação. Programar é elaborar, estabelecer um programa. Programa é o resultado, o produto da programação feita previamente por alguém ou, mais comumente, por uma comissão responsável pela organização do evento.

A programação, no caso dos congressos médicos, antecede de muito o congresso e demanda tempo para os preparativos do evento, como data, convites aos participantes, escolha dos temas oficiais, modo de apresentação, duração das sessões e outros pormenores. Uma vez tomadas todas as decisões, então sim, é impresso o programa, tanto da parte científica como da parte social do evento.

Em Informática, a distinção entre programa e programação é muito clara, como se depreende da leitura de sites em que são oferecidos programas para programação em computador.

1 Professor Emérito da Universidade Federal de Goiás.

Endereço para correspondência: E-mail: jmrezende@cultura.com.br http://usuarios.cultura.com.br/jmrezende

Recebido para publicação em: 14/11/2011. 
Em sentido mais amplo, emprega-se programação para anunciar um conjunto de programas a serem apresentados em cinema, teatro, rádio ou televisão E também como sinônimo de planejamento de cursos ou de realizações a serem cumpridas em qualquer empreendimento.

Para espetáculos e reuniões científicas e sociais de qualquer natureza, previamente programadas, deve-se usar programa e não programação.

\section{REFERÊNCIAS}

1. Houaiss A, Villar MS. Dicionário Houaiss da língua portuguesa. Rio de Janeiro, Objetiva, 2001.

2. Borba FS. Dicionário de usos do português do Brasil. São Paulo, Editora Ática, 2002.

3. Ferreira Aurélio Buarque de Holanda. Novo dicionário Aurélio da língua portuguesa, 3.ed. Curitiba, Ed. Positivo, 2004. 